\title{
Retrospective cohort analysis of 101 patients who underwent surgery due to spinal tumors: A single-center experience
}

\author{
Spinal tümörler nedeniyle ameliyat edilen 101 hastanın retrospektif kohort analizi: Tek merkez \\ deneyimi
}

Serkan Kitiş ${ }^{1}$, Meliha Gündağ Papaker ${ }^{1}$

\begin{abstract}
Aim: To evaluate the clinical and surgical outcomes of the spinal tumors operated in our clinic in order to provide an overview of the treatment strategies and outcomes of spinal tumors with the literature.

Methods: We retrospectively reviewed 101 spinal tumors patients who underwent microsurgical resection at our institution between January 2015 and January 2020. Data were collected consisting of the patients' clinics, demographic information, imaging methods, surgical approaches, neuropathological diagnosis, postoperative follow-up and complications, and postoperative neurological statuses. Frankel skore was used to assess neurological status of patients.

Results: 47 male and 54 female patients were followed-up for a mean period of 14.2 months. Intradural extramedullary $(51.5 \%)$, extradural $(36.6 \%)$ and intramedullary tumors $(11.9 \%)$ were seen, respectively. The most common localization was thoracic $(n=47)$, followed by lomber region $(n=26)$. The most frequent histopathological diagnosis was schwannoma $(n=27)$, meningioma $(n=19)$, metastasis $(n=19)$, ependymoma $(\mathrm{n}=11)$. According to the Frankel Scale, there was a decrease in the grades of two cases, an increase in the grades of 26 cases and no change in the grades of 73 cases. During follow-up with magnetic resonance imaging, it was observed that there were residual tumors, recurrence, and progression in $32.7 \%, 5.9 \%$ and $5.9 \%$ of the cases, respectively.

Conclusion: Despite the developing preoperative diagnostic methods, technological developments in peroperative tools and equipment, and the development of surgical techniques, the preoperative neurologica status remains the strongest predictor of postoperative function for spinal tumors. It is also important to determine the recurrence and progression rates of early magnetic resonance imaging examinations performed in patients during postoperative follow-up.
\end{abstract}

Keywords: Spinal tumor, Frankel Scale, histopathological diagnosis, magnetic resonance imaging.

Öz

Amaç: Spinal tümörlerin tedavi stratejileri ve sonuçlarına genel bir bakış sağlamak amacıyla kliniğimizde opere edilen spinal tümör olgularının klinik ve cerrahi sonuçlarını literatür eşliğinde değerlendirmektir.

Yöntemler: Ocak 2015 - Ocak 2020 tarihleri arasında kurumumuzda mikrocerrahi rezeksiyon uygulanan 101 spinal tümör hastası retrospektif olarak incelendi. Hastaların klinikleri, demografik bilgileri, görüntüleme yöntemleri, cerrahi yaklaşımlar, nöropatolojik tanı, postoperatif takip ve komplikasyonlardan oluşan veriler ve postoperatif nörolojik durumlar hakkındaki veriler toplandı. Hastaların nörolojik durumlarını değerlendirmek için Frankel skalası kullanıldı.

Bulgular: 47 erkek ve 54 kadın hasta ortalama 14.2 ay takip edildi. Yerleșim yerlerine göre intradural ekstramedüller (\% 51.5), ekstradural (\% 36.6) ve intramedüller tümörler $(\% 11.9)$ oranda görüldü. En sık yerleşim yeri torasik $(n=47)$, ardından lomber bölgeydi $(n=26)$. En sık görülen histopatolojik tanı schwannoma $(n=27)$, menenjiyom $(n=19)$, metastaz $(n=19)$ ve ependimoma $(n=11)$ idi. Frankel skalasına göre, iki olgunun derecesinde azalma, 26 olgunun derecesinde artış olmuştu ve 73 olgunun derecesinde ise değișiklik olmamıștı. Hastaların magnetik rezonans görüntüleme takiplerinde \% 32.7 rezidüel tümör, \% 5.9 rekürrens ve $\% 5.9$ progresyon olduğu görüldü.

Sonuç: Gelişen preoperatif tanı yöntemleri, peroperatif araç ve gereçlerdeki teknolojik gelişmeler ve cerrah tekniklerin gelişmesine rağmen, preoperatif nörolojik durum spinal tümörler için postoperatif fonksiyonun hala en güçlü prediktörü olmaya devam etmektedir. Ayrıca postoperatif takip sırasında hastalara yapılan erken magnetik rezonans görüntüleme incelemelerinin de nüks ve progresyon oranlarını belirlemede de önemlidir.

Anahtar Kelimeler: Spinal tümör, Frankel skalası, histopatolojik tanı, manyetik rezonans görüntüleme.
${ }^{1}$ Bezmialem Vakıf University, School of Medicine, Department of Neurosurgery, Istanbul, Turkey.

iD

SK: 0000-0002-9119-5899

MGP: 0000-0003-1271-9023

Ethics Committee Approval: The study was approved by Bezmialem University Ethical Committee (2020-7228).

Etik Kurul Onayı: Çalışma Bezmialem Üniversitesi Etik Kurulu tarafından onaylanmıștır (2020-7228).

Conflict of Interest: No conflict of interest was declared by the authors.

Çıkar Çatışması: Yazar çıkar çatışması bildirmemiștir.

Financial Disclosure: The authors declared that this study has received no financial support.

Finansal Destek: Yazarlar bu çalıșma için finansal destek almadıklarını beyan etmişlerdir.

Geliș Tarihi / Received: 27.06.2020

Kabul Tarihi / Accepted: 22.09.2020

Yayın Tarihi / Published: 31.08 .2020

Sorumlu yazar / Corresponding author:

Serkan Kitiş

Adres/Address: Adnan Menderes Bulvarı Vatan Caddesi 34093 Fatih, Istanbul, Turkey.

e-posta: serkankitis@yahoo.com

Tel/Phone: +90 2124531870

Copyright $(\mathcal{C}$ ACEM 


\section{Introduction}

Spinal tumors are major spinal pathologies that lead to significant morbidity and mortality, by causing radicular or local pain and neurological deficits such as limb dysfunction. These rare tumors affect a small proportion of the population. Although the most common symptom in patients is pain, the clinical presentation is often not disease specific. Most patients may confuse these tumors with degenerative spinal disease or intervertebral disc hernia. Accurate diagnosis and rapid treatment of spinal tumors are important because they can lead to significant morbidity in terms of pain and neurological deficits as well as death [1-3]. Regarding the differential diagnosis, the patient's age, topographic localization of the mass, and morphological features of the lesion shown by radiological examinations play an important role [4]. Preferred treatment is the microsurgical radical resection. The main goal in surgery is to make maximum neural tissue decompression and diagnose tissue while preserving neurological functions and stability.

The purpose of this study was to evaluate the clinical and surgical outcomes of the spinal tumor cases operated in our clinic in order to provide an overview of the treatment strategies and outcomes of spinal tumors with the literature. In addition to the clinical demographic information of the patients, their functional neurological status was investigated to evaluate the patients' quality of life after surgery.

\section{Material and methods}

Patient Data, Study Design, and Study Criteria:

We retrospectively reviewed 121 patients with spinal lesions who underwent microsurgical resection at our department between January 2015 and January 2020. This retrospective study was approved by the local medical ethics committee of Bezmialem University (2020-7228).

The medical data and demographic features of all the patients were collected according to the hospital records. The patients' clinics, demographic information, imaging methods, surgical approaches, neuropathological diagnosis, postoperative follow-up and complications, and postoperative neurological statuses were investigated.

The inclusion criteria were, all the patients who were diagnosed based on magnetic resonance imaging (MRI) findings and who underwent surgical resection due to a spinal tumor and which was proven pathologic diagnosis by histopathological examination. In addition age restrictions were not applied to the patients.

The excluded criteria were, patients undergoing diagnostic biopsy, patients who underwent resection of the spinal tumors determined using computerised tomography (CT) and not preoperative MRI. Also, patients who were not surgically treated, who were only diagnosed with radiological diagnosis and directed to oncological treatment were also excluded.

As a result, the study continued with 101 patients who met our criteria.

All of the cases were evaluated using MRI in the preoperative period. After surgical resection, the residual tumor was evaluated by performing an early postoperative MRI (in the first 24 hours). During the postoperative follow-up, control MRIs were performed and relapses were evaluated by a specialist radiologist and neurosurgeon.

The neurological status of each patient at presentation, early postoperative period and at the last follow-up were graded based on International Frankel Scale (FS) (Table 1). Functional result (FR) was obtained by comparing the FS values of the patients' preoperative and follow-up control examinations.

Table 1. Frankel Scale

\section{Class}

A Complete

B Sensory only

C Motor useless

D Motor usefull

E Recovery

\section{Severity}

No motor or sensory function below level of lesion

No motor function, but some sensation preserved below level of lesion

Some motor function without practicl application

Useful motor function below level of lesion

Normal motor and sensory function, may have reflex abnormalities

Functional status of the patients were evaluated according to the increase or decrease in the scores they received in FS.

The patients were operated under general anesthesia with a posterior, posterolateral, or anterior approach. We performed simple decompression, intradural tumor excision with laminoplasty, posterior stabilization with decompression, corpectomy and posterior stabilization using the posterior approach, and anterior corpectomy. Intraoperative neurophysiological monitoring (IONM) was use in necessary cases. Postoperative physical therapy protocol was applied to all patients. The necessary patients underwent oncological treatment (chemotherapy and/or radiotherapy) procedures.

\section{Statistical analysis}

SPSS 21.0 statistics program was used in our study. In addition to descriptive statistical methods, frequency, percentage, mean, standard deviation, and crosstabs analysis were used to describe the demographic characteristics of the cases. Data with normal distribution were evaluated by independent sample $t$ test. The normality of the distribution was assessed using the Kolmogorov Smirnov test. Pearson correlation test was used for correlation analysis. $\mathrm{P}$ values less than 0.05 were considered statistically significant.

\section{Results}

\section{Demographic and clinical features}

Of the 101 patients, 47 were males $(46.5 \%)$ and 54 were females $(53.5 \%)$. The youngest patient was 4 months old while the oldest was 82 years old (Mean $46.56 \pm 19.05$ ). Ninety two patients $(91 \%)$ were adults while 9 patients $(9 \%)$ were children $(<18$ years of age).

The time between the onset of symptoms and admission ranged from 1 day to 4 years. The patients were re-evaluated after an average of 14.7 months of follow-up.

The most common symptom was local pain (neck, back or low back pain) (63.3\%) and radicular pain (upper or lower limb pain) (37.6\%). 52 patients $(51.4 \%)$ presented with neurological deficits and 41 patients $(40.5 \%)$ presented with paresthesia. Sphincter dysfunction were present in 14 patients (13.8\%). Pathological reflexes, clonus and abnormality of deep tendon reflexes were found in 14 patients $(13.8 \%)$.

\section{Surgical treatment}

Sixty-five $(64.4 \%)$ patients underwent simple decompression, 21 $(20.8 \%)$ underwent intradural tumor excision with laminoplasty, $7(6.9 \%)$ underwent posterior stabilization with decompression, 3 (3\%) underwent corpectomy and posterior stabilization using the posterior approach, and 5 (4.9\%) underwent anterior corpectomy. 


\section{Histopathological and localization features}

Regarding the localization of the tumors, 1 was craniocervical, 18 were cervical, 1 was cervicothoracic, 47 were thoracic, 7 were thoracolumbar, 26 were lumbar and 1 was lumbosacral. It was observed that the most common location were intradural extramedullary $(50.5 \%)$, then extradural $(36.6 \%)$, and intramedullary (12.9\%).

According to the histopathological diagnosis, the most common pathology was Schwannoma (n: 27, 26.7\%) (Figure 1), then meningioma (n: 19, 18.8\%), metastasis (n: 19, 18.8\%) (Figure 2) and ependymoma (n: 11, 10.9\%). The detailed histopathological analysis of the tumors are shown in Table 2.

Table 2. Histopathological Features of tumors Pathology

$\mathrm{n}=101, \mathrm{n}(\%)$

\section{Schwannoma}

27 (26.7)

Meningioma

$19(18.8)$

Psammomatous meningioma

Transitional meningioma

Atypical meningioma

4 (4)

Anaplastic meningioma

Ependymoma

Myxopapillary ependymoma

$5(4.9)$

1 (1)

Subependymoma

3 (3)

Ependymoma (WHO grade 2)

Anaplastic Ependymoma

19 (18.8)

Metastasis

$4(4)$

Lung cancer

4 (4)

Breast cancer

2 (2)

Renal cell carcinoma

3 (3)

Prostate cancer

1 (1)

Cholangiocarcinoma

$1(1)$

Hepatocellular carcinoma

$1(1)$

Leiomyosarcoma

$1(1)$

Endometrial carcinoma

$1(1)$

Adenoid cystic carcinoma

$1(1)$

Nasopharyngeal carcinoma

$6(5.9)$

Lymphoma

3 (3)

Plasmacytoma

$2(2)$

$1(1)$

$2(2)$

1 (1)

1 (1)

$1(1)$

$1(1)$

$1(1)$

1 (1)

$1(1)$

1 (1)

$2(2)$

$1(1)$

Dermoid cysts

\section{Early postoperative evaluation}

When the early postoperative evaluations of the patients were examined, the mean hospitalization duration was $7.06 \pm 9.24$ days. Although the neurological examination of 80 patients did not change in comparison to the preoperative situation, those of
16 patients was found to be better compared to the preoperative situation, those of 5 patients got worse compared to the preoperative period, while one patient with mild paresis improved with physical therapy.

Three patients were reoperated due to postoperative hemorrhage and although a neurological function regression was observed in these 3 patients before the hemorrhage,

improvements were observed after reoperation. These same three patients later developed postoperative surgical site infections and were reoperated and treated with appropriate antibiotherapy. Postoperative cerebropsinal fluid (CSF) fistula developed in one case and was treated with lumbar external drainage. No deaths were record due to the surgeries.
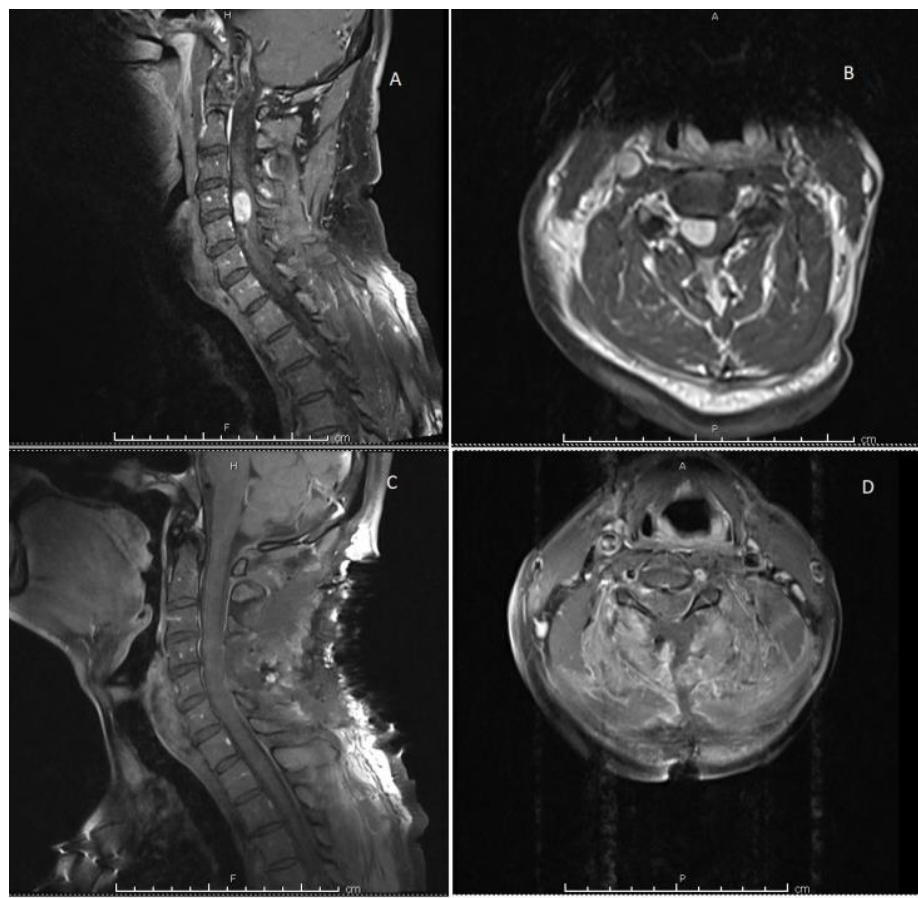

Figure 1. Cervical magnetic resonance images of a 62 year old male patient. Histopathological diagnosis Schwannoma. (a) Preoperative sagittal contrast enhanced T1 weighted image sequence showed that heterogeneous contrast enhancement lesion and (b) Preoperative axial T1 weighted image of heterogeneous contrast enhancement lesion. (c) Postoperative T1 weighted image sequence and (d) postoperative axial $\mathrm{T} 1$ weighted image appear to have a total removal of the lesion.

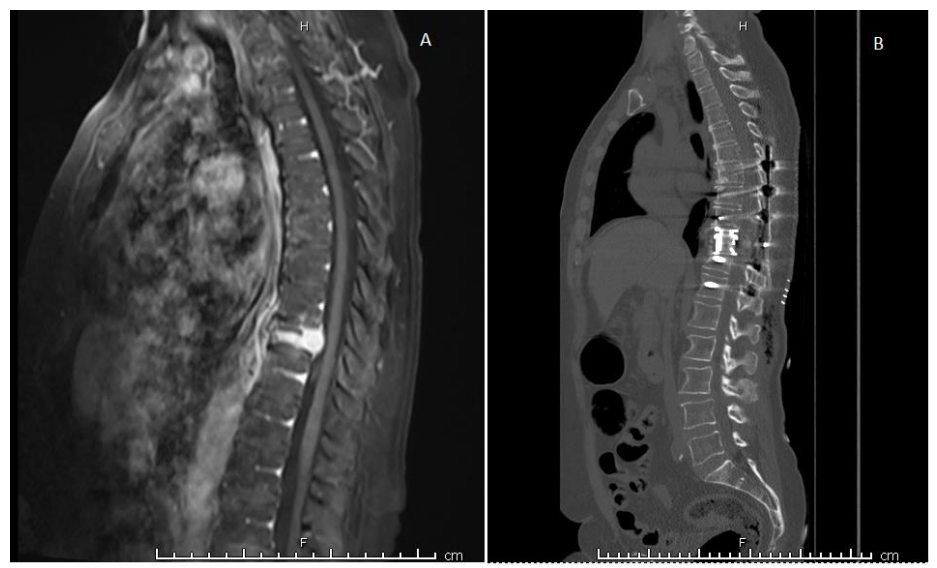

Figure 2: 44 year old female patient. Histopathological diagnosis hepatocellular carcinoma. (a) Preoperative sagittal contrast enhanced T1 weighted thoracic magnetic resonance images showed that T10 burst fracture compressed the spinal cord. (b) Postoperative computed tomography sagittal image showed that corpectomy and posterior stabilization using the posterior approach. 


\section{Radiological evaluation}

MRI results of the patients in the early postoperative period were compared with the control MRI results in the follow-up period. In the early postoperative period, $68(67.3 \%)$ patients had no residual tumor, while $33(32.7 \%)$ had residual tumors. On examination of the control MRIs performed during the patient follow-up, it was observed that recurrence occurred in 6 of 68 $(5.9 \%)$ patients without residual tumors and 2 of them were reoperated. It was observed that $24(23.8 \%)$ of 33 patients had stable residual tumors during follow-up, while $6(5.9 \%)$ had progressing tumors, 4 of which were. In $3(3 \%)$ patients (2 lymphomas and 1 ewing sarcoma), tumor regression was observed when they received oncological treatment after surgery (Table 3).

\section{Frankel scores and functional results}

When the preoperative Frankel scores were examined, 6 were grade A, 9 were grade $\mathrm{B}, 15$ were grade $\mathrm{C}$, and 22 were grade D and 49 were grade $\mathrm{E}$. At the follow-up control, six were grade A, three were grade $\mathrm{B}$, eight were grade $\mathrm{C}$, and 26 were grade $\mathrm{D}$ and 58 were grade $\mathrm{E}$. The preoperative neurological status was significantly related with the late postoperative outcome ( $\mathrm{p}$ $<0.001)$.

Table 3. Analysis of Functional Result and Radiological Evaluation according to histopathological changes

\begin{tabular}{|c|c|c|c|c|c|c|c|c|c|c|}
\hline \multirow[t]{2}{*}{ Pathology } & \multicolumn{5}{|c|}{ Functional Result } & \multicolumn{4}{|c|}{$\begin{array}{l}\text { Radiological } \\
\text { Evaluation }\end{array}$} & \multirow[t]{2}{*}{$\begin{array}{l}\text { To } \\
\text { tal }\end{array}$} \\
\hline & $\begin{array}{l}+ \\
2\end{array}$ & $\begin{array}{l}+ \\
1\end{array}$ & 0 & $\begin{array}{c}- \\
1\end{array}$ & $\overline{2}$ & $\begin{array}{l}\mathrm{R} \\
\mathrm{c}\end{array}$ & $\mathrm{P}$ & $S$ & $\begin{array}{l}\mathrm{R} \\
\mathrm{g}\end{array}$ & \\
\hline Schwannoma & & 4 & 22 & 1 & & & & 27 & & 27 \\
\hline $\begin{array}{l}\text { Psammomatous } \\
\text { meningioma }\end{array}$ & 1 & 1 & 8 & & & 1 & & 9 & & 10 \\
\hline Transitional meningioma & & 2 & 2 & & & & & 4 & & 4 \\
\hline Atypical meningioma & & 1 & 3 & & & & & 4 & & 4 \\
\hline Anaplastic meningioma & & 1 & & & & & 1 & & & 1 \\
\hline $\begin{array}{l}\text { Myxopapillary } \\
\text { ependymoma }\end{array}$ & & & 5 & & & & & 5 & & 5 \\
\hline Subependymoma & & & 1 & & & & & 1 & & 1 \\
\hline $\begin{array}{l}\text { Ependymoma (WHO } \\
\text { grade 2) }\end{array}$ & & & 3 & & & 1 & & 2 & & 3 \\
\hline Anaplastic ependymoma & & & 2 & & & & 1 & 1 & & 2 \\
\hline Metastasis & 1 & 5 & 13 & & & & 2 & 17 & & 19 \\
\hline Lymphoma & 1 & 2 & 3 & & & & & 4 & 2 & 6 \\
\hline Plasmacytoma & & 2 & 1 & & & & & 3 & & 3 \\
\hline $\begin{array}{l}\text { High grade gliomas } \\
\text { (WHO grade } 4 \text { ) }\end{array}$ & & & 2 & & & & 2 & & & 2 \\
\hline $\begin{array}{l}\text { Anaplastic astrocytomas } \\
\text { (WHO grade } 3 \text { ) }\end{array}$ & & 1 & & & & & & 1 & & 1 \\
\hline Neurofibroma & & & 2 & & & 1 & & 1 & & 2 \\
\hline Ganglioglioma & & & & & 1 & & & 1 & & 1 \\
\hline Ganglioneuroma & & & 1 & & & & & 1 & & 1 \\
\hline Epidermoid cysts & & & 1 & & & 1 & & & & 1 \\
\hline Myeloid sarcoma & & 1 & & & & & & 1 & & 1 \\
\hline $\begin{array}{l}\text { Malignant peripheral } \\
\text { nerve sheath tumor }\end{array}$ & & & 1 & & & 1 & & & & 1 \\
\hline Neuroblastoma & 1 & & & & & & & 1 & & 1 \\
\hline Immature teratoma & & & 1 & & & 1 & & & & 1 \\
\hline Angiolipoma & & & 1 & & & & & 1 & & 1 \\
\hline Ewing sarcoma & 1 & & 1 & & & & & 1 & 1 & 2 \\
\hline Lymphoma & & 1 & & & & & & 1 & & 1 \\
\hline
\end{tabular}

Rc: Recurrence, P: progressing, S: stable, Rg: regression

Functional result (FR) was obtained by comparing these Frankel Scale values of the patients' preoperative and control examinations. When the patients were re-evaluated of follow-up, according to the Frankel Scale, there was a decrease in the grade of two patients and an increase in the grade of 26 patients. There was no change in the grade of 73 patients (Figure 3). Two cases (2\%) whose FR deteriorated were intramedullary. In the examination of the 73 patients whose FR did not change, it was observed that patients with intradural extramedullary location maintained their status at a rate of $40.6 \%$, those with an intramedullary location at a rate of $8.9 \%$, and patients with an extradural location at a rate of $22.8 \%$. Of the patients with improved FR, $10.9 \%$ were found to be intradural extramedullary, $1 \%$ were intramedullary, and $13.9 \%$ were extradural (Figure 4 ). When the patients' tumor location were compared with preoperative FS ( $\mathrm{p}<0,001)$, follow-up FS $(\mathrm{p}=0.014)$ and FR (0.001), tumor location was associated with the clinical presentation of the patients. However, the relationship between the FR and the tumor level $(\mathrm{p}=0.430)$ were not statistically significant. Likewise, there was no statistically significant relationship between the FR and the the patients' gender $(\mathrm{p}=0.992)$ and age $(\mathrm{p}=0.907)$.

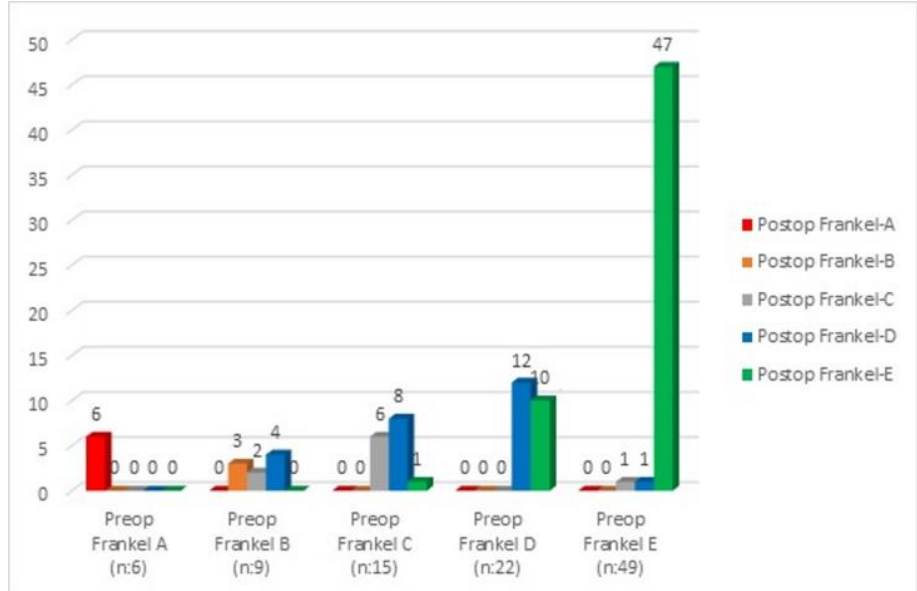

Figure 3. Preoperative (Preop) and postoperative (Postop) change of patients' Frankel Scores. According to this graph, all 6 patients with preop grade A all maintained their status as grade A during their followup. While 3 of 9 patients with preop grade B retained their status as grade B, 2 increase to grade $C$ and 4 to grade D. While 6 of 15 patients with preop grade $C$ retained their status as grade $C, 8$ increase to grade $\mathrm{D}$ and 1 to grade $\mathrm{E}$. While 12 of 22 patients with preop grade $\mathrm{D}$ remained as grade D, 10 increase to grade E. 1 of 49 patients with preop grade $\mathrm{E}$ decrease to grade $\mathrm{C}$ and 1 to grade $\mathrm{D}$.

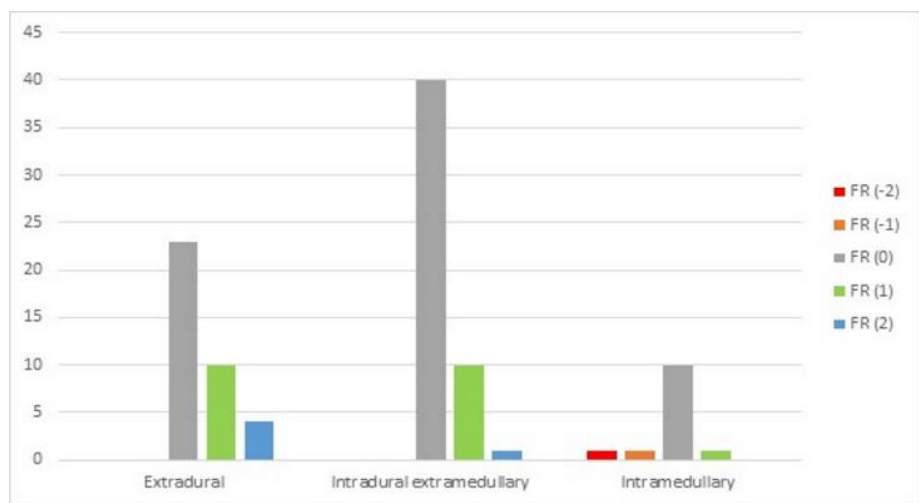

Figure 4. Relationship between tumor location and Functional result (FR) of patients.

While 23 of 37 patients with extradural tumors maintained their status, 10 of them increased 1 grade and 4 of them increased 2 grades. While 40 of 51 patients with intradural extramedullary tumor maintained their status, 10 of them increased 1 grade and 1 of them increased 2 grades. While 10 of 13 patients with intramedullary tumor maintained their status, 1 of them decrease of two grade and 1 of them decrease of one grade. 1 of them increased 1 grade. 


\section{Discussion}

Spinal tumors are rare lesions that are common in neurosurgical practice. They are life-changing and destructive conditions associated with ongoing disability, addiction, psychological stress, and financial burden $[5,6]$. It is importantly recommended to use clinical scores based on the neurological function to evaluate the prognosis after surgery. Some studies have shown that the most important prognostic factor is the initial functional state at the time of treatment $[7,8]$. In this study, we used the Frankel Scale to evaluate the functional result of patients before and after treatment. We found that the preoperative neurological status was significantly related with the late postoperative outcome. Also tumor location of patients was found to be related to functional result.

Neurological conditions of patients and sphincter functions are the most important factors affecting their quality of life. Therefore, early diagnosis of these lesions and appropriate treatment are important for the functional status of patients in the future. Pain, weakness, and sensory disturbances were found to be the most common symptoms and signs in these patients with spinal tumors. However, sphincter, bladder, and intestinal functions are impaired at a later stage [9-12]. Local pain $(63.3 \%)$ were the most common symptoms in our patients. In some studies, motor deficit was observed in $66-82 \%$ of cases, while it was observed in $51.5 \%$ of the patients in our study [6]. The incidence of urinary dysfunction $(13.9 \%)$ in our study was not as high as previously reported [10-12].

Today, with the advances in imaging methods, these lesions are better diagnosed and more information about the neurovascular structures is obtained. MRI is the gold standard method, which is at the center of radiological examinations for the classification of tumors by location [13]. Comparing the patients' early MRI with the control MRI is an important marker of relapse/rogression [14]. In our study, we found that how important early MRI examinations to patients were determining recurrence and progression rates in postoperative follow-up.

In general, secondary (metastatic) tumors are the most common spinal tumors and are most often are extradural. The spinal region is the third most common involvement site for metastatic tumors after the lung and liver [15]. Due to the prolonged life span of most cancer patients (20-40\%), the incidence of spinal metastasis increases during their illness and approximately $20 \%$ of these patients become symptomatic [ 16 , 17]. In our study, extradural tumors were seen with a second rate of $36.6 \%$ and metastatic tumors were the second most common with $18.8 \%$. According to the literature, the most important reason why metastatic tumors are in the second place is that patients who did not undergo surgery, who underwent biopsy with interventional techniques, and who received oncology/radiation oncology treatment were not included in the study.

Patients with primary spinal tumors are relatively rare. It has been reported that intradural extramedullary tumors are more common than intramedullary tumors [18-20]. In our study, $50.5 \%$ of the cases were intradural extramedullary and $12.9 \%$ of them were intramedullary in location. Schwannomas (26.7\%) and meningiomas $(18.8 \%)$, which are intradural extramedullary lesions, were common while ependymomas (10.9\%), which are among the intramedullary lesions, also occured frequently.

It has been reported in the literature that resection is the most effective treatment for well-limited benign intraspinal tumors and that surgical biopsy plays an important role in obtaining the histological diagnosis. It is not useful to perform a total resection in patients with malignant spinal cord tumors or in patients with a high probability of neurological injury. The purpose of surgery in partial resection is to obtain tissue for the definitive diagnosis, open the spinal cord as safely as possible, and to stabilize the spine in case of instability [21-24]. Decompressive laminectomy is one of the most used approaches in the treatment of spinal tumors. Several recent studies have shown that laminoplasty is superior to decompressive laminectomy in terms of prognosis and outcomes [25, 26]. Instability may occur during the surgical treatment of spinal tumors and methods requiring stabilization should be used [2729]. Therefore, more aggressive surgical strategies are sometimes required in the presence of severe instability and/or deformity [30-32]. We performed laminoplasty in 21 of 64 intradural tumors and simple decompression in 42 tumors, while one was decompressed with posterior stabilization. Of the five cases that underwent anterior corpectomy, four were cervical and one was thoracic in location, which were extradural tumors.

The limitation of our study is that it was a retrospective study in a relatively small group, since it only included spinal cases that were treated surgically and had only pathological diagnosis. Prospective studies with large and long follow-up are needed to systematically investigate these findings.

In conclusion, despite the increasing preoperative diagnostic methods, technological developments in peroperative tools and equipment, and the development of surgical techniques, the preoperative neurological status remains the strongest predictor of postoperative function for spinal tumors. It is also important to determine the recurrence and progression rates of early MRI examinations performed in patients during postoperative follow-up.

\section{References}

1. Sellin JN, Tatsui CE, Rhines LD. Assessment and treatment of benign intradural extramedullary tumors. In: Winn HR, editor. Youmans \& Winn Neurological Surgery. 7th ed. Philadelphia: Elsevier; 2017. p. 2428-34.e2.

2. Tobin MK, Geraghty JR, Engelhard HH, Linninger AA, Mehta AI. Intramedullary spinal cord tumors: a review of current and future treatment strategies. Neurosurg Focus. 2015;39:E14.

3. Fachrisal, Setiawan E, Alhuraiby SS. Functional outcome in intradural extramedullary tumor patients: Case series. Ann Med Surg (Lond). 2020;54:71-3

4. Ahlhelm FJ, Fries P, Nabhan A, Reith W. Spinale Tumoren [Spinal tumors]. Radiologe. 2010;50:165-80.

5. Maher de Leon ME, Schnell S, Rozental JM. Tumors of the spine and spinal cord. Semin Oncol Nurs. 1998;14:43-52.

6. Adeolu AA, Oyemolade TA, Salami AA, Adigun TA, Malomo AO, Akang EA, et al. Features and Outcome of Surgical Management of Spinal Tumors in a Cohort of Nigerian Patients. World Neurosurg. 2015;84:1090-4.

7. Frankel HL, Hancock DO, Hyslop G, Melzak J, Michaelis LS, Ungar $\mathrm{GH}$, et al. The value of postural reduction in the initial management of closed injuries of the spine with paraplegia and tetraplegia. I. Paraplegia. 1969;7:179-92.

8. Zairi F, Vieillard MH, Devos P, Aboukais R, Gras L, Assaker R. Management of neoplastic spinal tumors in a spine surgery care unit. Clin Neurol Neurosurg. 2015;128:35-40.

9. Balériaux DL. Spinal cord tumors. Eur Radiol. 1999;9:1252-8.

10. Newton HB, Newton CL, Gatens C, Hebert R, Pack R. Spinal cord tumors: review of etiology, diagnosis, and multidisciplinary approach to treatment. Cancer Pract. 1995;3:207-18.

11. Uchiyama T, Sakakibara R, Hattori T, Yamanishi T. Lower urinary tract dysfunctions in patients with spinal cord tumors. Neurourol Urodyn. 2004;23:68-75.

12. Wager M, Lapierre F, Blanc JL, Listrat A, Bataille B. Cauda equina tumors: a French multicenter retrospective review of 231 adult cases and review of the literature. Neurosurg Rev. 2000;23:119-31.

13. Van Goethem JW, van den Hauwe L, Ozsarlak O, De Schepper AM, Parizel PM. Spinal tumors. Eur J Radiol. 2004;50:159-76.

14. Ottenhausen M, Ntoulias G, Bodhinayake I, Ruppert FH Schreiber S, Förschler A, et al. Intradural spinal tumors in adults-update on management and outcome. Neurosurg Rev. 2019;42:371-88. 
15. Klimo P Jr., Schmidt MH. Surgical management of spinal metastases. Oncologist. 2004;9:188-96.

16. Barzilai O, Fisher CG, Bilsky MH. State of the Art Treatment of Spinal Metastatic Disease. Neurosurgery. 2018;82:757-69.

17. North RB, Larocca VR, Schwartz J, North CA, Zahurak M, Davis $\mathrm{RF}$, et al. Surgical management of spinal metastases: analysis of prognostic factors during a 10-year experience. J Neurosurg Spine.2005;2:564-73.

18. Hirano K, Imagama S, Sato K, Kato F, Yukawa Y, Yoshiara H, et al. Primary spinal cord tumors: review of 678 surgically treated patients in Japan. A multicenter study. Eur Spine J. 2012;21:2019-26.

19. Engelhard HH, Villano JL, Porter KR, Stewart AK, Barua M, Barker FG, et al. Clinical presentation, histology, and treatment in 430 patients with primary tumors of the spinal cord, spinal meninges, or cauda equina. J Neurosurg Spine. 2010;13:67-7.

20. Helseth A, Mørk SJ. Primary intraspinal neoplasms in Norway, 1955 to 1986. A population-based survey of 467 patients. J Neurosurg. 1989;71:842-5.

21. Abdel-Wahab M, Etuk B, Palermo J, Shirato H, Kresl J, Yapicier O, et al. Spinal cord gliomas: A multi-institutional retrospective analysis. Int J Radiat Oncol Biol Phys.2006;64:1060-71.

22. Constantini S, Miller DC, Allen JC, Rorke LB, Freed D, Epstein FJ. Radical excision of intramedullary spinal cord tumors: surgical morbidity and long-term follow-up evaluation in 164 children and young adults. J Neurosurg. 2000;93(2 Suppl):183-193.

23. Epstein FJ, Farmer JP, Freed D. Adult intramedullary astrocytomas of the spinal cord. J Neurosurg.1992;77:355-9.

24. Schwartz TH, McCormick PC. Intramedullary ependymomas: clinical presentation, surgical treatment strategies and prognosis. J Neurooncol. 2000; 47:211-8.

25. Chikani MC, Okwunodulu O, Mesi M, Mezue WC, Ohaegbulam SC, Ndubuisi CC. Surgically Treated Primary Spinal Cord Neoplasms in Southeastern Nigeria. J Neurosci Rural Pract. 2018;9:137-9.

26. Abd-El-Barr MM, Huang KT, Moses ZB, Iorgulescu JB, Chi JH. Recent advances in intradural spinal tumors. Neuro Oncol. 2018;20:729-42. 27. Dunning EC, Butler JS, Morris S. Complications in the management of metastatic spinal disease. World J Orthop. 2012;3:114-21.

28. Klimo P Jr, Schmidt MH. Surgical management of spinal metastases. Oncologist. 2004;9:188-96.

29. Matsumoto $Y$, Harimaya $K$, Doi $T$, Maeda $T$, Iwamoto $Y$. Outcome of osteoplastic laminotomy for excision of spinal cord tumours. J Orthop Surg (Hong Kong). 2009;17:275-9.

30. Hansen-Algenstaedt N, Kwan MK, Algenstaedt P, Chiu CK, Viezens L, Chan TS, et al. Comparison between minimally invasive surgery and conventional open surgery for patients with spinal metastasis: a prospective propensity score-matched study. Spine. 2017;42:789-97.

31. Hikata T, Isogai N, Shiono Y, Funao H, Okada E, Fujita N, et al. A Retrospective cohort study comparing the safety and efficacy of minimally invasive versus open surgical techniques in the treatment of spinal metastases. Clin Spine Surg. 2017;30:E1082-7.

32. Molina C, Rory Goodwin C, Abu-Bonsrah N, Elder BD, De La Garza Ramos R, Sciubba DM. Posterior approaches for symptomatic metastatic spinal cord compression. Neurosurg Focus. 2016;41:E11. 